\title{
Simple continuous-flow device for combined solar thermal pasteurisation and solar disinfection for water sterilisation
}

\author{
Anthony Amsberry ${ }^{1}$, Clayton Tyler ${ }^{2}$, William Steinhauff ${ }^{3}$, Justin Pommerenck ${ }^{4}$, \\ Alexandré T.F. Yokochi ${ }^{5}$ \\ Department of Chemical, Biological and Environmental Engineering, OSU, Corvallis OR \\ 19amsberra@onid.orst.edu, ${ }^{2}$ tylerc@onid.orst.edu, ${ }^{3}$ steinhaw@onid.orst.edu \\ ${ }^{4}$ pommerej@onid.orst.edu, ${ }^{5}$ alex.yokochi@orst.edu
}

\begin{abstract}
A collection unit and reflective concentrators were used to thermally preheat water to at least $70^{\circ} \mathrm{C}$ for thermal pasteurisation prior to a solar disinfection stage. The device is offered as a novel combined cycle to be used for either solar thermal pasteurisation, during seasonal peaks in solar irradiation, or as a solar preheat for UV solar disinfection that would occur in a flow-through solar disinfection trough. Inexpensive materials were used in order to simulate in field functionality and applicability to rural regions with low solar input. Solar incidence at Oregon State University, with latitude $45.5^{\circ}$, was recorded during trials conducted during May 1 to June 10 for the purpose of directly scaling the water treatment volumetric flowrate of the device for any future tests in other locations. This scaling by solar irradiation makes this dataset useful for other locations with higher or lower solar input and needing more or less treated water. The simple gravity-fed continuous system presented in this article makes use of a large cold-water reservoir, a shell-and-tube heat exchanger, and a solar collector. The system, operating at flowrates of 100-150 $\mathrm{mL} / \mathrm{min}$ is able to reach outlet temperatures of $74^{\circ} \mathrm{C}$. The system is projected to produce $55 \mathrm{~L}$ of purified water daily when operating on a sunny day with peak UV radiation above $700 \mathrm{~W} / \mathrm{m}^{2}$. System cost was $\$ 55$ with an added optional $\$ 15$ for the shell-and-tube heat exchanger.
\end{abstract}

KEYWORDS: Rural water sanitisation, SOPAS, SODIS, solar thermal pasteurisation, drinking water.

\section{1}

\section{INTRODUCTION}

There is a fundamental gap between the effectiveness of water sanitisation mechanisms in developed countries as opposed to their lower starting capital implementation in under-developed rural regions (Kaushal \& Varun, 2010). There have been a variety of attempts to address the lack of available drinking water in rural areas of undeveloped nations. A summary of those technologies that have been employed in rural communities was offered (Khattab et al, 2011). Most test systems employ either solar disinfection or thermal pasteurisation and have been used to effectively treat water in developing countries. It has been demonstrated that wastecooking heat from fire pits can be extracted and used to treat village water supplies (Islam \& Johnston, 2006). The only disadvantage is the scalability of system capacity for water sanitisation. Dayem et al (2012) produced a parabolic trough concentrating solar collector, which is an example of some of the continuous flow systems Dayem et al. (2012) point out the efficient passive flow temperature regulation of the purification system developed by Duff \& Hodgson (2005). Flat plate concentrators have been effective in enabling 100 L capacity batch pasteurisation (Onyango et al, 2009). In field pasteurisation setups have been successful at the $\$ 2,000$ capital cost for $200 \mathrm{~L} /$ day (Konersmann \& Frank, 2011). Typically, large buffer reservoirs and thermostats are required to monitor acceptably treated water and safely store it for periods of lesser solar insolation. These continuous systems safely pasteurise continuous flows of water (Saitoh \& Ghetany, 1999).

Solar disinfection uses UV from direct sunlight to irradiate low turbidity water in clear containers. The DNA inactivation of coliforms in water has been studied extensively (Centers for Disease Control and Prevention, 2008). This process can be carried out in batch steps such as in PET water bottles (Conroy et 
al, 1996; Joyce et al 1996; Walker et al, 2004; Félix et al, 2009; Marques et al, 2013).

Tremendous is the concept of a synergistic interplay between the UV inactivation of coliform DNA and temperature. Safapour \& Metcalf (1999) noted that in one minute at $50^{\circ} \mathrm{C}$ there was a one log removal of coliforms. McGuigan et al (1998) characterised this synergy. A mechanistic description of this synergy quickly followed (Oates et al, 2003).

Suggested is a combined cycle purification system (CCPS) which can be operated in either solar pasteurisation mode (Mode 1) or in conjunction with solar disinfection (Mode 2). Solar pasteurisation is a useful method of water disinfection in areas with high solar incidence. If the synergistic interplay between temperature and UV inactivation of coliform DNA does occur as described in McGuigan et al (1998) and Safapour et al (1999), the proposed combined cycle can reduce the wait time for solar disinfection (SODIS) from one to two days to minutes.

The thermal concentrator unit preheats the water to be treated with direct sunlight. The heated water can be treated in a glass topped solar disinfection trough, which has been properly engineered to allow for the residence time necessary for the water to be properly exposed to direct sunlight. A heat recuperator can be used after the solar disinfection to recapture the waste heat and preheat the incoming water in a continuous CCPS. The thermal concentrator is a continuous-flow, gravity-fed system with flat reflectors that uses a simple solar oven to heat influent water to either pasteurisation temperature (70 ${ }^{\circ} \mathrm{C}$ for 7 minutes) or more preferably to synergistic SODIS temperatures (held at 45 to $60^{\circ} \mathrm{C}$ under direct UV during SODIS). Continuous-flow systems are more efficient at heating water than large batch systems, due to increased heat transfer from the heated surfaces, which prevents waste heat from being lost to the environment. Device efficiency is a major factor in sustainable operation. Solar ovens are closed boxes with a clear face that traps heat from incoming solar radiation.

There have been several previous continuous-flow designs that make use of a solar collector and metal absorber plate beneath an array of tubing placed in parallel lines. The use of a metal absorber plate beneath the array of tubing increases heat transfer to flowing water by up to $16 \%$ (Cramer et al, 2013).

The project objective was to develop a simple system that could be easily built and operated in underdeveloped nations. The prototype is detailed in

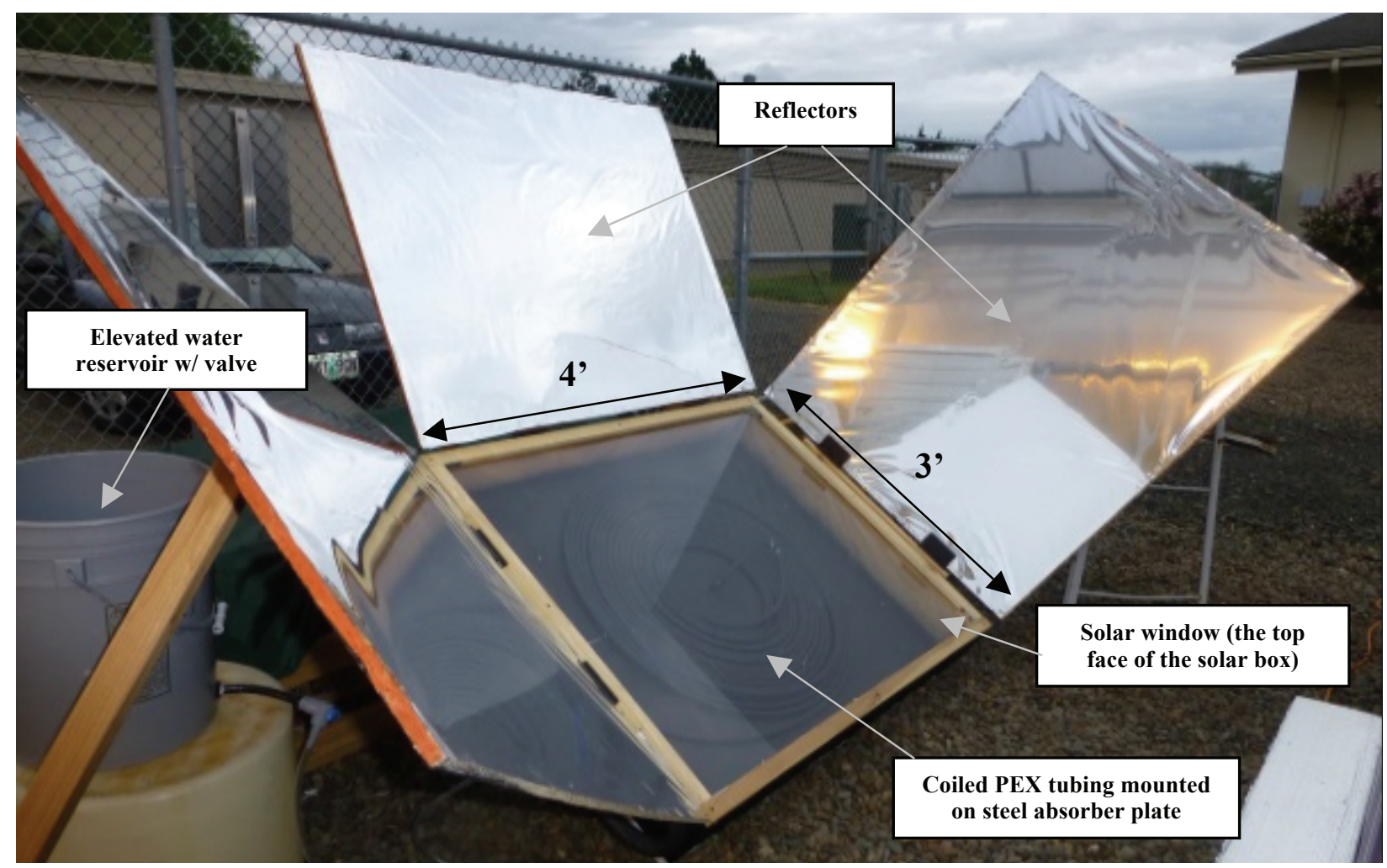

Figure 1: The built prototype. The $1 \mathrm{~m} \times 1.3 \mathrm{~m}$ solar collector has three reflectors to maximise irradiative sunlight into the box. Water flows through $33.3 \mathrm{~m}$ of PEX tubing mounted on a $1 \mathrm{~m} \times 1.3 \mathrm{~m}$ steel plate and is sealed with a solar window (clear plastic sheet) to prevent heat loss. The heat exchanger, which uses the hot water exiting the solar collector to preheat the water that is about to enter the solar collector, is mounted on the side of the box. Outer connective tubing that carries hot water is insulated in order to prevent unnecessary heat loss. 
this report. This system is unique in that the tubing is coiled circularly, simplifying the construction process of the array. One can simply lay the tubing in the box and attach it to the base plate. The unit is confined to a small space and has $1 \mathrm{~m}^{2}$ solar concentrating plates which can collapse for ease of transportation if not fabricated on site. The unit weighs less than $68 \mathrm{~kg}$ (150 lbs).

\section{THE PROTOTYPE DEVICE}

\subsection{Fabrication}

The prototype device consists of a solar collector, a heat exchanger, and an elevated reservoir to hold contaminated water. The solar collector (solar box) was built from plywood, lumber, window-insulating plastic, $33.3 \mathrm{~m}$ of PEX tubing, a metal absorber plate, reflective Mylar, hinges, and screws. Figure 1 is a labelled photograph of the solar collector.

A simple shell-and-tube heat exchanger was built from a $1.2 \mathrm{~cm}$ OD copper pipe mounted inside a $2.54 \mathrm{~cm}$ OD PVC pipe (shell). Detailed fabrication instructions are provided upon request.

\subsection{Experimentation}

Figure 2 shows a plot of temperature vs. time for the air and outlet water in the solar box. The system was tested at various water flowrates, and the dynamic and steady-state temperatures of the water and of the interior air in the solar box were recorded in Figures 3 and 4 .

Figure 2 shows that the outlet water temperature can exceed the interior air temperature of the box. This is significant because it suggests that heat transfer is not limited by conduction through the PEX plastic surface. If the PEX plastic surface did transfer heat the air within the box more rapidly, this would mean that the air would soon become closer to the outlet temperature of the water. This shows the origin of the heat is from direct irradiation of the black PEX tubing. The loss mechanism is primarily into the colder $50^{\circ} \mathrm{C}$ air inside the box and then to the box lid or wood before radiating or it is convectively lost to the $21^{\circ} \mathrm{C}$ ambient air outside of the water treatment unit.

The optimal flowrate for reaching pasteurisation temperatures is about $150 \mathrm{~mL} / \mathrm{min}$, as seen from Figure 3. Using $150 \mathrm{~mL} / \mathrm{min}$, the daily purified water volume was estimated and compared with daily UV radiation (Figure 4 ).

The solar thermal pasteurisation design works at $700 \mathrm{~W} / \mathrm{m}^{2}$ or more (for $55 \mathrm{~L}$ ) and for that duration of time only. That is the water that is purified. That is the water the village will get that day. That is why combined cycle purification systems (CCPS) or Mode 2 are important using this new synergy between temperature and UV, SODIS becomes possible at high throughputs. This means that even early in the morning and in the evening, water is being produced. The system in Mode 1 projected to produce $55 \mathrm{~L}$ of

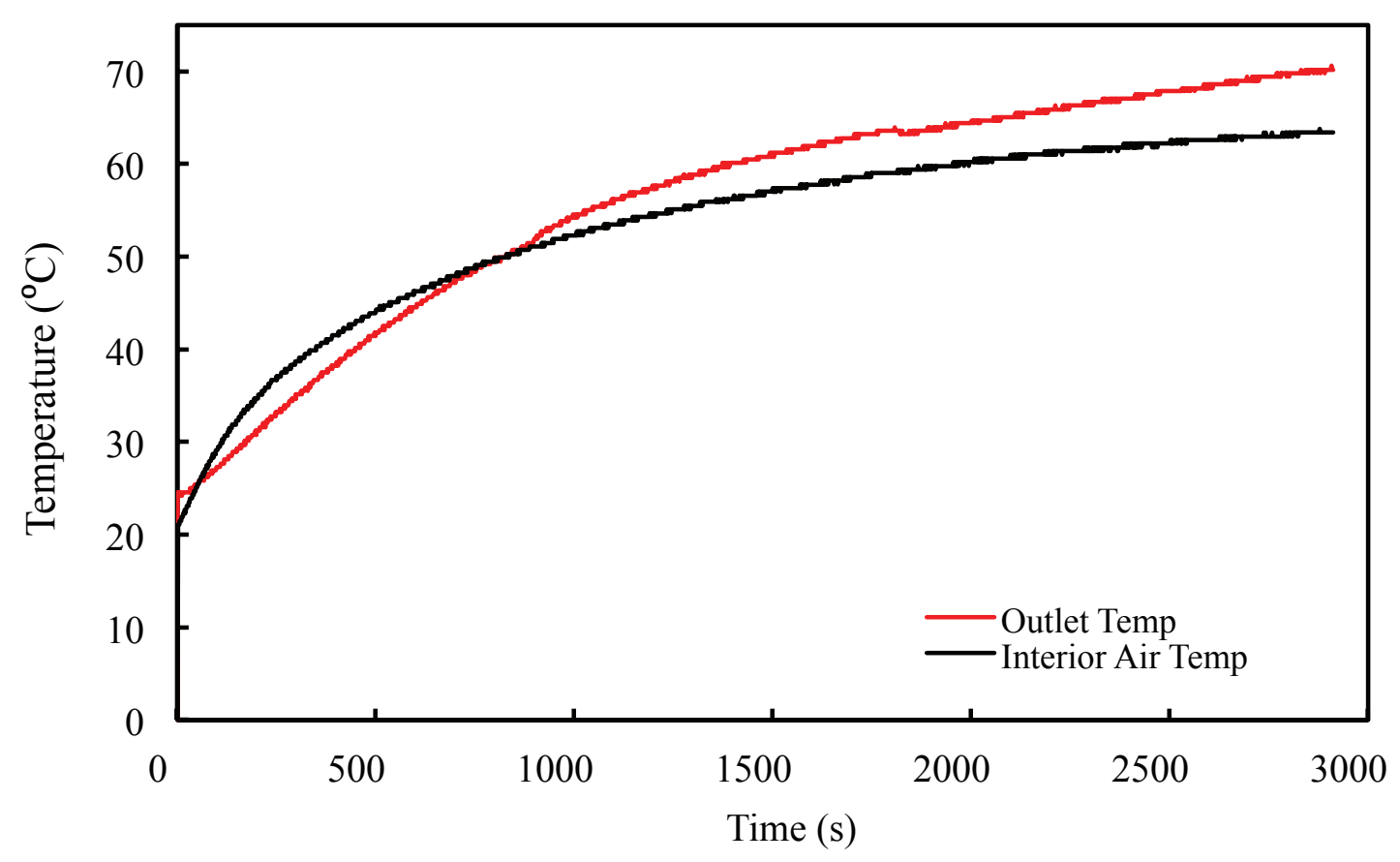

Figure 2: $\quad$ Temperature $\left({ }^{\circ} \mathrm{C}\right)$ vs. time (s) for interior air inside the box and the water exiting the solar collector. The water flowrate was set at approximately $150 \mathrm{~mL} / \mathrm{min}$. Data collection took place once the solar box was opened up and reflectors positioned to focus all light on the box. 


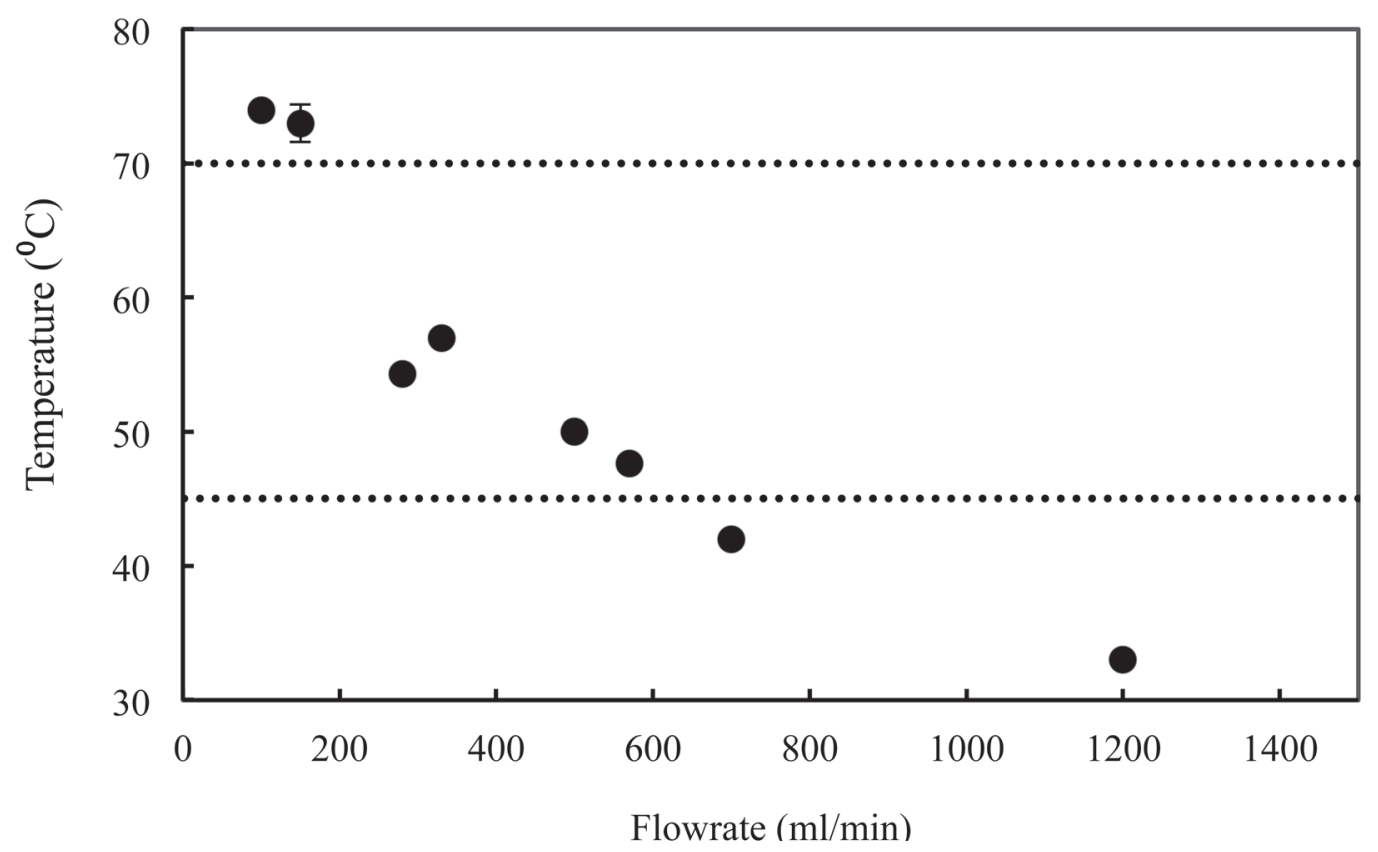

Figure 3: $\quad$ Steady state water temperature $\left({ }^{\circ} \mathrm{C}\right)$ exiting the solar collector vs. water flowrate ( $\left.\mathrm{mL} / \mathrm{min}\right)$. Data was collected on three separate sunny days, and the cold inlet water temperature was fixed at $22^{\circ} \mathrm{C}$. Horizontal lines show target pasteurisation temperature $\left(70{ }^{\circ} \mathrm{C}\right)$ and target outlet temperature for the SODIS step $\left(45^{\circ} \mathrm{C}\right)$.

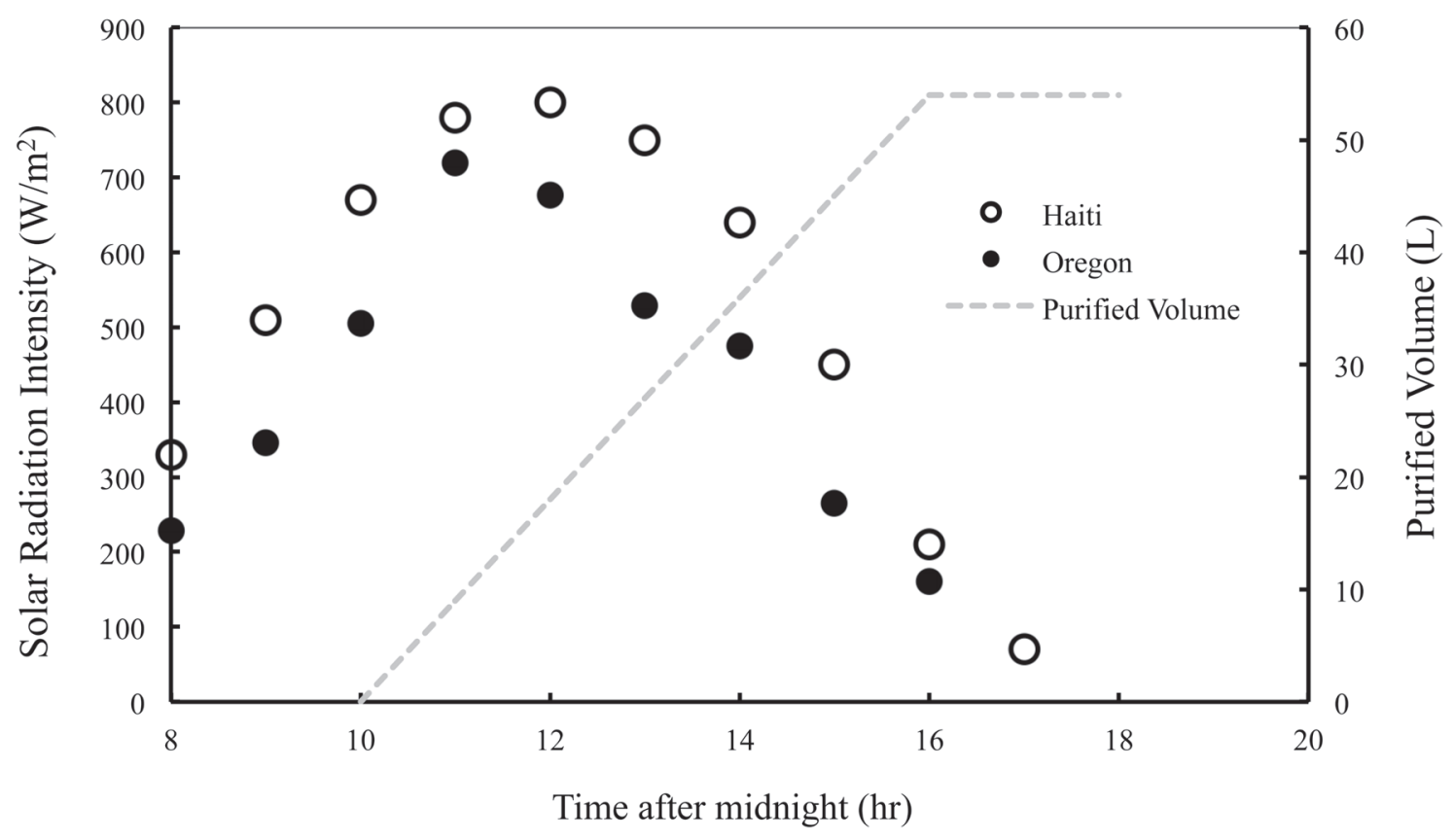

Figure 4: $\quad$ Average daily solar irradiance $\left(\mathrm{W} / \mathrm{m}^{2}\right)$ for Haiti (lat. $\left.19^{\circ}\right)$ and Oregon (lat. $45.5^{\circ}$ determined by scaling average daily irradiance at lat. $\left.40.5^{\circ}\right)$. Cumulative purified water volume represents predicted daily yield at a water flowrate of $150 \mathrm{~mL} / \mathrm{min}$, assuming operation at peak hours (10:00-16:00). Haiti was chosen as a country for comparison due to the abundant annual sunlight. Source: Oates et al (2002).

purified water daily when operating on a sunny day with peak UV radiation above $700 \mathrm{~W} / \mathrm{m}^{2}$ applies to almost everywhere in the world. Figure 5 shows solar insolation $\left(\mathrm{W} / \mathrm{m}^{2}\right)$ as a function of latitude and time of day.

\section{CONCLUSION}

A unique water purification device has been proposed that makes use of two sterilisation techniques. The combined system is promising because it has the ability to purify large amounts 


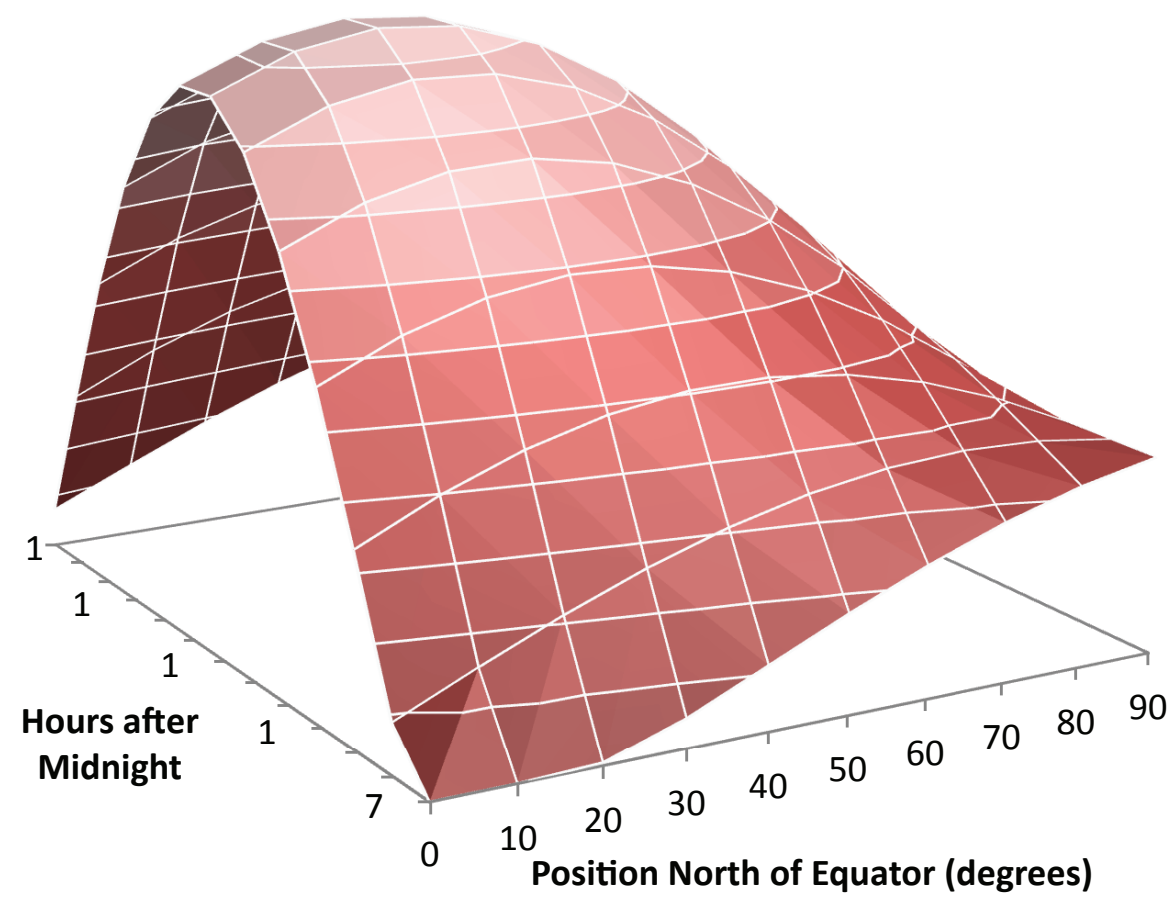

Insolation $\left(\mathrm{W} / \mathrm{m}^{2}\right)$

1000-1100

- 900-1000

- 800-900

- 700-800

- 600-700

- 500-600

- 400-500

- 300-400

- 200-300

- 100-200

- 0-100

Figure 5: Three dimensional plot showing the change in solar insolation $\left(\mathrm{W} / \mathrm{m}^{2}\right)$ with respect to the position in degrees north from the equator. All data was calculated using the Bird Simplified Clear Sky Model Solar Insolation Model for June 1. Source: Bird \& Hulstrom (1981).

of water per day through rapid pre-heating and SODIS that takes less time than normal SODIS. The use of an insulated holding tank after the pre-heater allows the system operator to transfer water to PET bottles at a time that is most convenient for the user or fabricate a continuous flow chamber for UV irradiation with heat recuperation. This represents an efficient continuous flow sanitation system that meets the needs of solar thermal pasteurisation for higher solar irradiation and can be used for combined cycle purification systems (CCPS).

\subsection{Alternative function of device}

The solar collector can also be used as a waterpreheater, prior to bathing, washing, or boiling water (for cooking or water purification). Pre-heating water before boiling reduce the time and fuel requirements (fire wood) needed to reach boiling point.

\subsection{Limitations}

Pasteurisation rates of $55 \mathrm{~L} /$ day were achieved under test conditions with peak solar incidence of $700 \mathrm{~W} /$ $\mathrm{m}^{2}$. Combined cycle purification systems utilising this device at the same peak irradiation could except $220 \mathrm{~L} /$ day to be delivered at $45{ }^{\circ} \mathrm{C}$ to the UV disinfection trough. The CCPS is capable of pasteurising large amounts of water for locations with significant sunshine, yet there are limitations to the system.
The materials used in this prototype are not entirely feasible for an underdeveloped location where such materials cannot be easily obtained. The essential components (heat exchanger, tubing, etc.) should be prepared ahead of time and delivered to the community. Also, the use of alternative materials should be considered. The black body used in the prototype made use of black spray paint and sheet metal, which is not readily available in developing nations. An alternative, such as black charcoal, should be considered. PEX tubing is very rigid and difficult to attach to the base plate without drilling holes and using fasteners. The design should use more-flexible tubing that is still inert at high temperatures and safe to hold drinking water. The Styrofoam insulation could easily be replaced by folded paper or cardboard.

One drawback of Mode 1 operation is that it is difficult to gauge how long the water has been held at pasteurisation temperature within the PEX tubing. An adiabatic holding loop prior to the heat exchanger could be used to ensure that the water remained warm enough for the desired amount of time. Typical holding time at $70^{\circ} \mathrm{C}$ is from 0.3 to $1 \mathrm{~min}$ for the UK pasteurisation standard.

Mode 2 operation could make use of an adiabatic holding tank following the solar collector, prior to long-term UV exposure in separate PET bottles or 
another device designed to expose the hot water to solar irradiation.

A heat recuperator can be used after each of the setups. The heat exchanger takes the hot (already pasteurised or UV treated water) and recovers the heat using adjacent counter-current flow on the outside of the pipe carrying the sanitary water. This means hot water is produced in one stream and cold potable water in the other.

\subsection{Cultural Considerations}

This design does not consider issues associated with implementation of the device. No analysis was done on the culture and lifestyle of the potential implementation community, and therefore it is uncertain as to how this device would integrate into the foreign culture. A solution has been provided, without fully understanding the complexity of the problem. A preliminary visit to the implementation site would be necessary to ensure that this device would work for a community in Haiti. This visit would include determination of specific foreign parameters (community size, water demand, contaminated water source, UV radiation patterns, etc.) and observation of lifestyle and cultural factors. An excellent suggestion for implementation requested a more participatory method, particularly for construction and operation. The best solution might be designing workshops with communities in order to gain feedback for eventual prototype testing in each respective country.

\subsection{Future Work}

The device was built and tested as if clear low-turbidity water that is heated to a certain temperature would effectively kill all harmful bacteria. However, the effluent water was not tested for coliform reduction. Future work should include microbial testing of effluent water in an actual rural community to ensure sufficient reduction of indicator contaminants (eg, E. coli).

A pre-filter is always used with SODIS or solar thermal pasteurisation. The turbidity of the water must be low for UV disinfection to become effective. A simple cloth or sand and gravel filter easily meets these goals, but adds to system cost and construction requirements. A pre-filter should be used prior to the reservoir holding unsterilised water to remove large particulates. A simple filter (eg, a stretched cloth or a packed bed of gravel and sand) should be integrated into the system prior to implementation.

The heat exchanger cools outlet water, which will increase the time required for UV disinfection. The heat exchanger can be moved downstream of any continuous flow UV irradiation chamber to which the preheat exchanger is connected for heat recuperation.

\section{ACKNOWLEDGEMENTS}

Manfred Dittrich provided enriching advice and machining support for undergraduate research at the university. Thanks are directed to Jim Ervin for providing outdoor testing space at Oregon State and Andy Brickman for technical support. This project was performed as part of the senior development course at Oregon State and benefited greatly from the time, energy and guidance of the course instructor Dr. Philip Harding, the Linus Pauling Distinguished Engineer.

\section{REFERENCES}

Abdel Dayem, A.M., El-Ghetany, H.H., El-Taweel, G.E., MKamel, M., 2012, 'Thermal performance and biological evaluation of solar water disinfection systems using parabolic trough collectors', Desalination and Water Treatment, vol. 36, no. 1-3, pp. 119-128, doi: 10.5004/dwt.2011.2227

Centers for Diseases Control and Prevention, 2008, Household Water Treatment Options in Developing Countries: Solar Disinfection (SODIS), viewed 10 July 2013, <http:/ / www.cdc.gov/safewater / publications_pages/options-sodis.pdf>

Conroy, R.M., Elmore-Meegan, M., Joyce, T., McGuigan, K.G., Barnes, J., 1996, 'Solar disinfection of drinking water and diarrhoea in Maasai children: a controlled field trial', Lancet, vol. 348, no. 9043, pp. 1695-7.

Cramer, S., Jasch, K., McIntyre, S., O'Malley, K., Ragozzino, B., Reed, J., Xiong. J., \& George, C., 2006, Solar Powered Water Pasteurizer, University of St. Thomas, viewed 10 July 2013, <http:/ / courseweb. stthomas.edu/cmgeorge/projects / english/solar_ water_pasteurizer/solarWaterPasteurizer.htm>

Islam, M.F., \& Johnston, R.B., 2006, 'Household Pasteurization of Drinking-water: The Chulli Watertreatment System', viewed 10 July 2013, International Center for Diarrhoel Disease Research, vol. 23, no. 3, pp. 356-362.

Duff, W.S., \& Hodgson, D.A., 2005, 'A simple high efficiency solar water purification system', Solar Energy, vol. 79, no. 1, pp. 25-32, doi: 10.1016/j. solener.2004.10.005

Félix, L.F., Cuardros-Orellana, S., Lima, A.S., Meira de Souza. L.C., \& Araújo, P.M.M., 2009, 'Solar Water Disinfection in Northeast Brazil: Kinetics of the Process and the Study for the Development of a Pilot Plant', Journal of Engineering Science and Technology, vol. 4, no. 3, pp. 328-343.

Joyce, T.M., McGuigan, K.G., Elmore-Meegan, M., Conroy, R.M., 1996, 'Inactivation of fecal bacteria in drinking water by solar heating', Applied and Environmental Microbiology, vol. 62, no. 2, pp.399-402.

Kaushal, A. \& Varun, 2010, 'Solar stills: A Review', 
Renewable and Sustainable Energy Reviews, vol. 14, no. 1, pp. 446-453, doi:10.1016/j.rser.2009.05.011

Khattab, N.M., Soliman, H., Metias, M., El-Seesy, I., Mettawee, E., El-Shenawy,. E and Hassan, M., 2011, 'Implementation of Solar Technologies in the Development of Rural, Remote and Sub urban Communities', International Journal of Thermal and Environmental Engineering, vol. 3, no. 2, pp. 59-66, doi: 10.5383 /ijtee.03.02.001

Konersmann, L. \& Frank, E., 2011, Solar Water Disinfection: Field Test Results and Implementation Concepts, viewed 10 July 2013, <http: / / swisswaterkiosk.org /wp-content/ uploads/2011/08/110817_SWC_Paper.pdf >

Marques, A.R., de Cássia Oliveira Gomes, F., Fonseca, M.P.P, Parreira, J.S., \& Santos, V.P., 2013, 'Efficiency of PET reactors in solar water disinfection for use in southeastern Brazil', Solar Energy, vol. 87, pp. 158-167, doi: 10.1016/j.solener.2012.10.016

McGuigan, K.G., Joyce, T.M., Conroy, R.M., Gillespie, J.B., \& Elmore-Meegan, M., 1998, 'Solar disinfection of drinking water contained in transparent plastic bottles: characterizing the bacterial inactivation process', Journal of Applied Microbiology, vol. 86, no. 6, pp. 1138-48.
Oates, P.M., Shanahan, P., \& Polz, M.F., 2003, 'Solar disinfection (SODIS): simulation of solar radiation for global assessment and application for point-ofuse water treatment in Haiti', Water Research, vol. 37, no. 1, pp. 47-54.

Onyango, E.A., Thoruwa, T.F.N., Maingi, S.M., Njagi, E.M., 2009, 'Performance of a 2-Element Plane Reflector Augmented Galvanised Pipe Flat Plate Collector for Solar Water Pasteurisation', Journal of Food Technology, vol. 7, no. 1, pp 12-19.

Safapour, N., \& Metcalf, R.H., 1999, 'Enhancement of Solar Water Pasteurization with Reflectors', Applied Environmental Microbiology, vol. 65, no. 2, pp. 859-861.

Saitoh, T.S., \& El-Ghetany, H.H., 1999, 'Solar watersterilization system with thermally-controlled flow', Applied Energy, vol. 64, no. 1-4, pp. 387-399, doi: 10.1016/S0306-2619(99)00086-0

Walker, D.C., Len, S.V., \& Sheehan, B., 2004, 'Development and Evaluation of a Reflective Solar Disinfection Pouch for Treatment of Drinking Water', Applied and Environmental Microbiology, vol. 70, no. 4, pp. 2545-2550, doi: 10.1128/ AEM.70.4.2545-2550.2004 